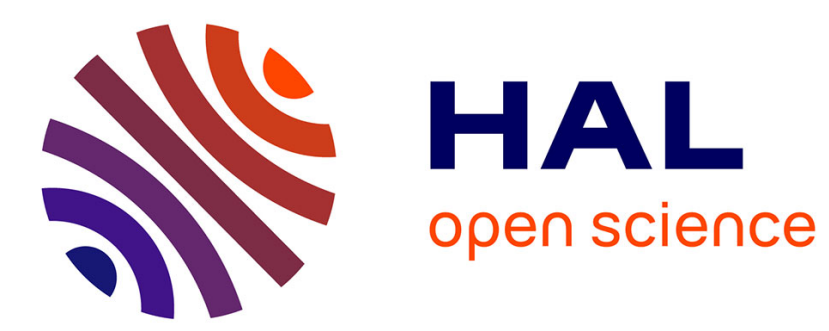

\title{
A Study of the NOx Selective Catalytic Reduction with Ethanol and Its By-products
}

A. Flura, X. Courtois, F. Can, S. Royer, D. Duprez

\section{To cite this version:}

A. Flura, X. Courtois, F. Can, S. Royer, D. Duprez. A Study of the NOx Selective Catalytic Reduction with Ethanol and Its By-products. Topics in Catalysis, 2013, 56 (1-8), pp.94-103. 10.1007/s11244013-9935-2 . hal-00840145

\section{HAL Id: hal-00840145 \\ https://hal.science/hal-00840145}

Submitted on 22 Jan 2021

HAL is a multi-disciplinary open access archive for the deposit and dissemination of scientific research documents, whether they are published or not. The documents may come from teaching and research institutions in France or abroad, or from public or private research centers.
L'archive ouverte pluridisciplinaire HAL, est destinée au dépôt et à la diffusion de documents scientifiques de niveau recherche, publiés ou non, émanant des établissements d'enseignement et de recherche français ou étrangers, des laboratoires publics ou privés. 
Topics in catalysis 56 (2013) 94-103.

DOI: $10.1007 / \mathrm{s} 11244-013-9935-2$

\title{
A study of the NOx selective catalytic reduction with ethanol and its by-products.
}

\author{
A. Flura, X. Courtois*, F. Can, S. Royer, D. Duprez
}

Institut de Chimie des Milieux et des Matériaux de Poitiers (IC2MP), UMR 7285 Université de Poitiers-CNRS, 4 rue Michel Brunet, F-86022 Poitiers Cedex, France

*Corresponding author: Tel.: 33(0)549453994, e-mail: xavier.courtois@univ-poitiers.fr.

\begin{abstract}
The NOx Selective Catalytic Reduction (SCR) with ethanol has been investigated over alumina supported silver catalyst with a special attention to the main involved reactions depending on the temperature test. With this aim, the possible reducers from ethanol transformations were also evaluated $\left(\mathrm{C}_{2} \mathrm{H}_{5} \mathrm{OH}, \mathrm{CH}_{3} \mathrm{CHO}, \mathrm{C}_{2} \mathrm{H}_{4}, \mathrm{CO}\right)$. In addition, the contributions of the gas phase reactions and the alumina support were also pointed out.

Based on the $\mathrm{C}$-products and $\mathrm{N}$-compounds distributions, it is assumed that at low temperature $\left(\mathrm{T}<300^{\circ} \mathrm{C}\right)$, ethanol reacts firstly with $\mathrm{NO}+\mathrm{O}_{2}$ to produce acetaldehyde and $\mathrm{N}_{2}$. For higher temperatures, two reaction pathways have been proposed, supported by the $\mathrm{CH}_{3} \mathrm{CHO}-\mathrm{SCR}$ results: a direct reaction between $\mathrm{NO}_{2}$ and $\mathrm{CH}_{3} \mathrm{CHO}$, or via $-\mathrm{NCO}$ species.
\end{abstract}

Keywords: $\mathrm{NOx}, \mathrm{SCR}$, ethanol, $\mathrm{Ag} / \mathrm{Al}_{2} \mathrm{O}_{3}, \mathrm{NH}_{3}$, acetaldehyde 


\section{Introduction}

In addition to the emission control of pollutants such as CO, hydrocarbons, NOx and particulates, the reduction of the greenhouse gases emission, as $\mathrm{CO}_{2}$, also becomes stricter. As a consequence, the use of engines working in lean condition is very attractive. However, the usual three way-catalyst is not able to reduce NOx in excess of oxygen and other catalytic processes were proposed to achieve expected NOx abatement. One possible solution is to use NOx storage reduction (NSR) catalysts [1], which works in lean/rich cycling condition. The major drawback of this system is the possible deactivation of the catalyst, mainly due to sulfur poisoning [2,3] or thermal ageing [4-6]. Moreover, possible emission of $\mathrm{NH}_{3}$ and $\mathrm{N}_{2} \mathrm{O}$, a strong greenhouse gas, were also reported $[7,8]$.

The second way to reduce NOx is the Selective Catalytic Reduction (SCR). For this process, numerous reducers have been investigated, such as hydrocarbons [9-11], oxygenated compounds [11-13] or nitrogen containing compounds (ammonia, urea,...) [14-16]. Recently, development of bio-ethanol gasoline aroused the interest for NOx SCR by ethanol. Alumina supported silver materials are reported to be the more efficient catalysts [17-19], and the reaction mechanism has been investigated in numerous studies [17,20-22]. A global overview is presented Figure 1. In this work, the NOx SCR with ethanol (EtOH-SCR) was studied over a $2 \mathrm{wt} . \% \mathrm{Ag} / \mathrm{Al}_{2} \mathrm{O}_{3}$ catalyst with a special attention to the main reactions involved depending on the temperature. With this aim, the possible reducers derived from ethanol (i.e. $\mathrm{CH}_{3} \mathrm{CHO}, \mathrm{C}_{2} \mathrm{H}_{4}$, $\mathrm{CO}$ ) were also evaluated. In order to understand the role of the gas phase reactions, as well as the catalytic reactions on the alumina support and the silver active phase, experiments were performed using three different conditions: i) without catalyst; ii) in presence of the $\mathrm{Al}_{2} \mathrm{O}_{3}$ support and iii) in presence of the $\mathrm{Ag} / \mathrm{Al}_{2} \mathrm{O}_{3}$ catalyst.

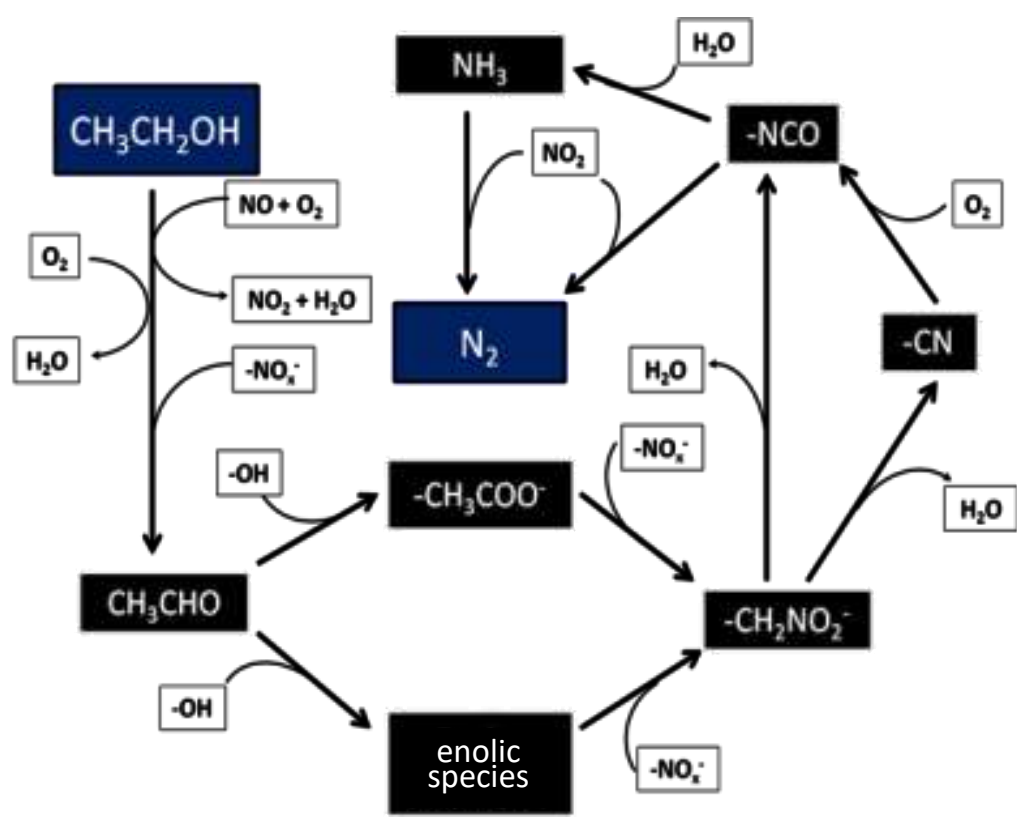

Figure 1: Global overview of EtOH-SCR mechanism 


\section{Experimental}

The alumina support was synthesized using a sol-gel route [23]. Silver (2.0wt.\%) was added by impregnation in ethanol [24]. Sample was finally calcined under air $+10 \% \mathrm{H}_{2} \mathrm{O}$ at $600^{\circ} \mathrm{C}$ for $4 \mathrm{~h}$, and exhibits a specific surface area of $263 \mathrm{~m}^{2} \mathrm{~g}^{-1}$ (pore volume $1.13 \mathrm{~cm}^{3} \mathrm{~g}^{-1}$ ). X-ray diffraction pattern evidences the $\gamma-\mathrm{Al}_{2} \mathrm{O}_{3}$ phase [ICDD PDF $\mathrm{n}^{\circ} 00-050-0741(\mathrm{I})$ ] with no visible reflection assigned to silver species $\left(\mathrm{Ag}^{0}, \mathrm{Ag}_{2} \mathrm{O}, \mathrm{AgO}, \mathrm{Ag}_{2} \mathrm{Al}_{2} \mathrm{O}_{4} \ldots\right)$. $\mathrm{H}_{2}$-TPR result reveals that $66 \%$ of the deposited silver is in metallic state, according to Musi et al [25]. TEM experiments show that $\mathrm{Ag} / \mathrm{Al}_{2} \mathrm{O}_{3}$ presents a low silver particles size distribution, most of the particles ranging below $10 \mathrm{~nm}$.

Standard catalytic tests were performed under mixture of 400ppm NO, 500ppm CO, 167ppm $\mathrm{H}_{2}, 1200 \mathrm{ppm} \mathrm{C}_{2} \mathrm{H}_{5} \mathrm{OH}, 8 \% \mathrm{O}_{2}, 10 \% \mathrm{H}_{2} \mathrm{O}, 10 \% \mathrm{CO}_{2}$ balanced in $\mathrm{N}_{2}$. The GHSV is fixed at $150,000 \mathrm{~h}^{-1}$. Catalytic tests were also performed with other reducers, keeping the $\mathrm{C} / \mathrm{N}$ ratio constant $(\mathrm{C} / \mathrm{N}=6)$. Systematically, thermal decomposition (without catalyst) and catalytic reaction (alumina support alone or $\mathrm{Ag} / \mathrm{Al}_{2} \mathrm{O}_{3}$ catalyst) were performed for each gas mixture depicted in Table 1. Results are expressed as conversion or yield. Note that the NO conversion represents the global NO disappearance, i.e. taking into account both the NO oxidation into $\mathrm{NO}_{2}$ and the $\mathrm{NO}$ reduction.

Table 1: Gas mixtures of the main catalytic tests at constant GHSV of $150000 \mathrm{~h}^{-1}$.

\begin{tabular}{|l|c|c|c|c|c|c|c|c|}
\hline Gas mixture & $\begin{array}{c}\mathrm{HC}^{*} \\
(\mathrm{ppm})\end{array}$ & $\begin{array}{c}\mathrm{NO} \\
(\mathrm{ppm})\end{array}$ & $\begin{array}{c}\mathrm{CO} \\
(\mathrm{ppm})\end{array}$ & $\begin{array}{c}\mathrm{H}_{2} \\
(\mathrm{ppm})\end{array}$ & $\begin{array}{c}\mathrm{O}_{2} \\
(\%)\end{array}$ & $\begin{array}{c}\mathrm{CO}_{2} \\
(\%)\end{array}$ & $\begin{array}{c}\mathrm{H}_{2} \mathrm{O} \\
(\%)\end{array}$ & $\mathrm{N}_{2}$ \\
\hline $\mathrm{HC}^{*}$-SCR (standard) & 1200 & 400 & 500 & 167 & 8 & 10 & 10 & balance \\
\hline $\mathrm{HC}^{*}-\mathrm{SCR}$ (simplified) & 1200 & 400 & - & - & 8 & - & - & balance \\
\hline $\mathrm{HC}^{*}-\mathrm{NO}$ & 1200 & 400 & - & - & & - & - & balance \\
\hline $\mathrm{HC}^{*}$ decomposition & 1200 & - & - & - & - & - & - & balance \\
\hline $\mathrm{HC}^{*}$ oxidation & 1200 & - & - & - & 8 & - & - & balance \\
\hline $\mathrm{NO}^{\circ}$ oxidation & - & 400 & - & $(167)$ & 8 & - & $(10)$ & balance \\
\hline $\mathrm{CO}-\mathrm{SCR}$ & - & 400 & 500 & - & 8 & - & - & balance \\
\hline
\end{tabular}

$\mathrm{HC}^{*}: \mathrm{CH}_{3} \mathrm{CH}_{2} \mathrm{OH}$ or $\mathrm{CH}_{3} \mathrm{CHO}$ or $\mathrm{C}_{2} \mathrm{H}_{4}$

Most gases (NO, $\mathrm{NO}_{2}, \mathrm{~N}_{2} \mathrm{O}, \mathrm{NH}_{3}, \mathrm{CO}, \mathrm{CO}_{2}, \mathrm{C}_{2} \mathrm{H}_{5} \mathrm{OH}, \mathrm{CH}_{3} \mathrm{CHO}, \mathrm{C}_{2} \mathrm{H}_{4}$ ) were analyzed using a Multigas FTIR detector (MKS 2030). The $\mathrm{N}_{2}$ selectivity is calculated assuming that no other $\mathrm{N}$ compounds than $\mathrm{NO}, \mathrm{NO}_{2}, \mathrm{~N}_{2} \mathrm{O}, \mathrm{NH}_{3}$ are emitted. In fact, no $\mathrm{N}_{2} \mathrm{O}$ emission was detected whatever the catalytic test conditions. 


\section{Results and discussion}

3.1 Standard-SCR behaviors over $\mathrm{Ag} / \mathrm{Al}_{2} \mathrm{O}_{3}\left(\mathrm{C}_{2} \mathrm{H}_{5} \mathrm{OH}-\mathrm{SCR}, \mathrm{CH}_{3} \mathrm{CHO}-\mathrm{SCR}, \mathrm{C}_{2} \mathrm{H}_{4}-\mathrm{SCR}\right)$

Catalytic results obtained on $\mathrm{Ag} / \mathrm{Al}_{2} \mathrm{O}_{3}$ catalyst for the standard $\mathrm{C}_{2} \mathrm{H}_{5} \mathrm{OH}$-SCR test (Table 1) are presented in Figure $2 \mathrm{~A}$ and Figure $2 \mathrm{~B}$ for $\mathrm{C}$-compounds and $\mathrm{N}$-compounds yields, respectively. A comparison of the NOx conversion depending on the introduced hydrocarbon $\left(\mathrm{C}_{2} \mathrm{H}_{5} \mathrm{OH}, \mathrm{CH}_{3} \mathrm{CHO}\right.$ or $\left.\mathrm{C}_{2} \mathrm{H}_{4}\right)$ is also illustrated in Figure $2 \mathrm{C}$.
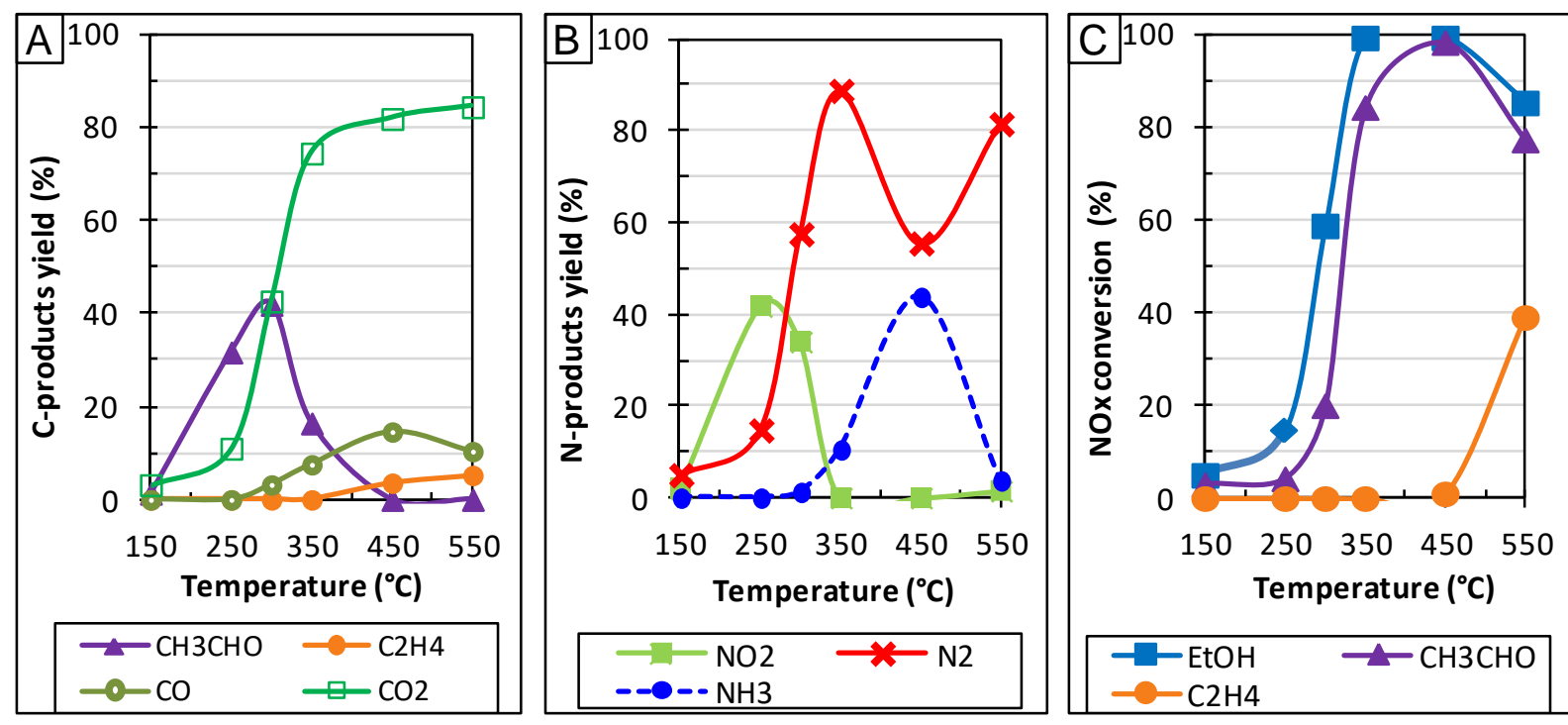

Figure 2: Standard-SCR tests over $\mathrm{Ag} / \mathrm{Al}_{2} \mathrm{O}_{3}$. (A) C-compound yields and (B) $\mathrm{N}$-compound yields with $\mathrm{EtOH}$ as reducer. (C) NOx conversion in SCR with $\mathrm{C}_{2} \mathrm{H}_{5} \mathrm{OH}, \mathrm{CH}_{3} \mathrm{CHO}$ or $\mathrm{C}_{2} \mathrm{H}_{4}$ as reducer.

$\mathrm{C}_{2} \mathrm{H}_{5} \mathrm{OH}$-SCR test over $\mathrm{Ag} / \mathrm{Al}_{2} \mathrm{O}_{3}$ (Figure 2A) shows that acetaldehyde is the main C-product emitted at low temperature $\left(250^{\circ} \mathrm{C}\right)$. Low ethylene concentration is also observed at high temperature $\left(450-550^{\circ} \mathrm{C}\right)$. Maximum CO yield $(17 \%)$ is observed at $450^{\circ} \mathrm{C}$. The $\mathrm{N}$-compounds distribution (Figure $2 \mathrm{~B}$ ) shows the emission of $\mathrm{NO}_{2}$ and $\mathrm{NH}_{3}$, in addition to $\mathrm{N}_{2}$. In fact, the main $\mathrm{N}$-compound product is nitrogen from $300^{\circ} \mathrm{C}$, whereas, at $250^{\circ} \mathrm{C}$, important amount of $\mathrm{NO}_{2}$ is detected. An important $\mathrm{NH}_{3}$ formation is observed at $450^{\circ} \mathrm{C}\left(\mathrm{NH}_{3}\right.$ yield: $\left.43 \%\right)$, which induces a strong decrease of the $\mathrm{N}_{2}$ yield at this temperature.

Using the standard condition (Table1), Figure 2C shows that both ethanol and acetaldehyde are efficient to reduce NOx. Total NOx conversion is achieved at $350^{\circ} \mathrm{C}$ with ethanol. A shift of $25-50^{\circ} \mathrm{C}$ to higher temperatures is observed when acetaldehyde is used. Ethylene is not active until $450^{\circ} \mathrm{C}$, but NOx conversion reaches $38 \%$ at $550^{\circ} \mathrm{C}$. Indeed, it appears from Figure 2C, that ethanol, acetaldehyde and, to a lesser extent ethylene, are effective reducers for the NOx abatement in excess of $\mathrm{O}_{2}$. Thereafter, in order to clarify the role of each reducer, the reactivity of the C-containing reducers $\left(\mathrm{C}_{2} \mathrm{H}_{5} \mathrm{OH}, \mathrm{CH}_{3} \mathrm{CHO}, \mathrm{C}_{2} \mathrm{H}_{4}, \mathrm{CO}\right)$ has been examined in detail using simplified gas mixtures, with special attention to the $\mathrm{N}$-compounds distribution. 
3.2 Understanding the role of the gas phase reaction, alumina and silver supported catalyst: simplified-SCR behaviors $\left(\mathrm{C}_{2} \mathrm{H}_{5} \mathrm{OH}-\mathrm{SCR}, \mathrm{CH}_{3} \mathrm{CHO}-\mathrm{SCR}, \mathrm{C}_{2} \mathrm{H}_{4}-\mathrm{SCR}\right)$

Efficiency of various hydrocarbons $\left(\mathrm{C}_{2} \mathrm{H}_{5} \mathrm{OH}, \mathrm{CH}_{3} \mathrm{CHO}, \mathrm{C}_{2} \mathrm{H}_{4}\right)$ in $\mathrm{NOx}$ SCR in simplified condition $\left(\mathrm{HC}+\mathrm{NO}+\mathrm{O}_{2}\right.$, Table 1$)$ is studied in this section. Catalytic tests were carried out always keeping the same introduced $\mathrm{C} / \mathrm{N}$ ratio and GHSV. The $\mathrm{CO}$ behavior toward NO in excess of oxygen was also examined. In order to understand the role of each parameter, a special attention is focused on the influence of the condition test: without catalyst, in presence of alumina, or with $\mathrm{Ag} / \mathrm{Al}_{2} \mathrm{O}_{3}$.

Firstly, with $\mathrm{CO}$ as reducer (400ppm NO $+500 \mathrm{ppm} \mathrm{CO}+8 \% \mathrm{O}_{2}$ gas mixture), no SCR activity is observed in thermal condition as well as with $\mathrm{Al}_{2} \mathrm{O}_{3}$ or $\mathrm{Ag} / \mathrm{Al}_{2} \mathrm{O}_{3}$ catalyst. $\mathrm{CO}_{2}$ is nevertheless detected, but only with $\mathrm{Ag} / \mathrm{Al}_{2} \mathrm{O}_{3}$ and at high temperature $\left(550^{\circ} \mathrm{C}\right)$.

With $\mathrm{C}_{2} \mathrm{H}_{4}$ as reducer, it is concluded that ethylene is not thermally decomposed and does not react with $\mathrm{NO}$ or $\mathrm{O}_{2}$ alone. It was observed that $\mathrm{C}_{2} \mathrm{H}_{4}$ is converted $(30 \%)$ only at $550^{\circ} \mathrm{C}$ in presence of both $\mathrm{NO}+\mathrm{O}_{2}$. The main product is then $\mathrm{CO}$ and $\mathrm{NO}_{2}$. The $\mathrm{N}_{2}$ formation is negligible (9ppm). On alumina $\mathrm{C}_{2} \mathrm{H}_{4}$ also reacts with $\mathrm{NO}+\mathrm{O}_{2}$, but only at $550^{\circ} \mathrm{C}$. Comparison with the gas phase test indicates that $\mathrm{NO}_{2}$ produced in the gas phase is converted on alumina, and the $\mathrm{N}_{2}$ yield reaches $43 \%$ at $550^{\circ} \mathrm{C}$. Finally, with $\mathrm{Ag} / \mathrm{Al}_{2} \mathrm{O}_{3}, \mathrm{NO}$ conversion is detected from $450^{\circ} \mathrm{C}(20 \%)$, but $\mathrm{NO}_{2}$ is the major product. At $550^{\circ} \mathrm{C}$, the $\mathrm{N}_{2}$ yield $(53 \%)$ is just a little improved with silver.

Comparative results in $\mathrm{CH}_{3} \mathrm{CHO}-\mathrm{SCR}$ and $\mathrm{C}_{2} \mathrm{H}_{5} \mathrm{OH}-\mathrm{SCR}$ at different temperatures are presented in Table 2.

Concerning $\mathrm{CH}_{3} \mathrm{CHO}-\mathrm{SCR}$ tests, surprisingly, $\mathrm{NO}$ conversion is similar either in thermal condition or with $\mathrm{Al}_{2} \mathrm{O}_{3}$ sample, but the $\mathrm{N}$-compounds selectivity is greatly modified, as reported in Table 2. In fact, in thermal condition, $\mathrm{NO}$ conversion mainly leads to $\mathrm{NO}_{2}$ formation, even if $\mathrm{N}_{2}$ concentration also calculated. With $\mathrm{Al}_{2} \mathrm{O}_{3}, \mathrm{NO}_{2}$ emission is not observed before $450^{\circ} \mathrm{C}$, and the drop of $\mathrm{NO}_{2}$ yield observed with alumina is concomitant with a significant increase in $\mathrm{N}_{2}$ emission. This result suggests that, using $\mathrm{CH}_{3} \mathrm{CHO}$ as reducer, the $\mathrm{N}_{2}$ formation on alumina is correlated with the amount of $\mathrm{NO}_{2}$ produced in thermal condition, upstream of the catalyst. Note that the $\mathrm{NO}_{2}$ yields observed in thermal condition is in accordance with the $\mathrm{NO} / \mathrm{NO}_{2}$ thermodynamic equilibrium.

Compared with alumina, $\mathrm{CH}_{3} \mathrm{CHO}$ and $\mathrm{NO}$ conversions are enhanced with silver supported catalyst. Addition of silver on alumina leads to an increase of the $\mathrm{N}_{2}$ yield from $50 \%$ to $88 \%$ at $450^{\circ} \mathrm{C}$, whereas the $\mathrm{NO}_{2}$ yields are nil for both samples (Table 2). In this case, $\mathrm{N}_{2}$ emission is not limited by the $\mathrm{NO}_{2}$ formed upstream of the catalyst. This result clearly implies that silver species are active for $\mathrm{NO}$ oxidation into $\mathrm{NO}_{2}$. These results seem to indicate that the $\mathrm{NO}_{2}$ 
formation is an important step of the $\mathrm{CH}_{3} \mathrm{CHO}-\mathrm{SCR}$ mechanism, as reported in the literature [26].

For $\mathrm{C}_{2} \mathrm{H}_{5} \mathrm{OH}-\mathrm{SCR}$, in thermal condition, $\mathrm{NO}$ conversion is effective essentially at $550^{\circ} \mathrm{C}$ (conv.: $92 \%$ ) and it mainly leads to $\mathrm{NO}_{2}$ (Table 2). On $\mathrm{Al}_{2} \mathrm{O}_{3}$, the $\mathrm{NO}$ conversion varies from $55 \%$ to $80 \%$ between $350^{\circ} \mathrm{C}$ and $550^{\circ} \mathrm{C}$. The $\mathrm{N}_{2}$ yield reaches a maximum of $48 \%$ at $450^{\circ} \mathrm{C}$. Interestingly, the $\mathrm{NO}_{2}$ yield at $550^{\circ} \mathrm{C}$ is lower on alumina (45\%), than without any catalyst $(78 \%)$. Ammonia is never observed in thermal condition, or with $\mathrm{Al}_{2} \mathrm{O}_{3}$.

Table 2: Comparative results in $\mathrm{CH}_{3} \mathrm{CHO}$ and $\mathrm{C}_{2} \mathrm{H}_{5} \mathrm{OH}-\mathrm{SCR}$ in simplified condition (reducer + $\mathrm{NO}+\mathrm{O}_{2}$ ). Reducer conversion, $\mathrm{NOx}$ conversion and $\mathrm{N}$-compound yields for reaction in thermal condition, with $\mathrm{Al}_{2} \mathrm{O}_{3}$ or with $\mathrm{Ag} / \mathrm{Al}_{2} \mathrm{O}_{3}$.

\begin{tabular}{|c|c|c|c|c|c|c|c|c|c|}
\hline & & \multicolumn{4}{|c|}{$\mathrm{CH}_{3} \mathrm{CHO}+\mathrm{NO}+\mathrm{O}_{2}$} & \multicolumn{4}{|c|}{$\mathrm{C}_{2} \mathrm{H}_{5} \mathrm{OH}+\mathrm{NO}+\mathrm{O}_{2}$} \\
\hline & & $250^{\circ} \mathrm{C}$ & $350^{\circ} \mathrm{C}$ & $450^{\circ} \mathrm{C}$ & $550^{\circ} \mathrm{C}$ & $250^{\circ} \mathrm{C}$ & $350^{\circ} \mathrm{C}$ & $450^{\circ} \mathrm{C}$ & $550^{\circ} \mathrm{C}$ \\
\hline \multirow{3}{*}{$\begin{array}{l}\text { C- } \\
\text { reducer } \\
\text { conv. } \\
(\%)\end{array}$} & Thermal & 0 & 1 & 9 & 62 & 0 & 0 & 8 & 49 \\
\hline & $\mathrm{Al}_{2} \mathrm{O}_{3}$ & 0 & 22 & 89 & 100 & 38 & 95 & 100 & 100 \\
\hline & $\mathrm{Ag} / \mathrm{Al}_{2} \mathrm{O}_{3}$ & 2 & 54 & 100 & 100 & 46 & 100 & 100 & 100 \\
\hline \multirow{3}{*}{$\begin{array}{l}\mathrm{NO} \\
\text { conv. } \\
(\%)\end{array}$} & Thermal & 0 & 10 & 48 & 79 & 0 & 0 & 3 & 92 \\
\hline & $\mathrm{Al}_{2} \mathrm{O}_{3}$ & 0 & 10 & 50 & 83 & 3 & 55 & 60 & 80 \\
\hline & $\mathrm{Ag} / \mathrm{Al}_{2} \mathrm{O}_{3}$ & 8 & 22 & 99 & 90 & 28 & 69 & 100 & 90 \\
\hline \multirow{3}{*}{$\begin{array}{l}\mathrm{N}_{2} \\
\text { yield (\%) }\end{array}$} & Thermal & 0 & 2 & 9 & 27 & 0 & 0 & 1 & 14 \\
\hline & $\mathrm{Al}_{2} \mathrm{O}_{3}$ & 0 & 10 & 50 & 48 & 2 & 35 & 48 & 35 \\
\hline & $\mathrm{Ag} / \mathrm{Al}_{2} \mathrm{O}_{3}$ & 1 & 22 & 88 & 55 & 14 & 65 & 76 & 58 \\
\hline \multirow{3}{*}{$\begin{array}{l}\mathrm{NO}_{2} \\
\text { yield (\%) }\end{array}$} & Thermal & 0 & 8 & 39 & 52 & 0 & 0 & 2 & 78 \\
\hline & $\mathrm{Al}_{2} \mathrm{O}_{3}$ & 0 & 0 & 0 & 35 & 1 & 20 & 12 & 45 \\
\hline & $\mathrm{Ag} / \mathrm{Al}_{2} \mathrm{O}_{3}$ & 7 & 0 & 0 & 35 & 14 & 0 & 0 & 32 \\
\hline \multirow{3}{*}{$\begin{array}{l}\mathrm{NH}_{3} \\
\text { yield (\%) }\end{array}$} & Thermal & 0 & 0 & 0 & 0 & 0 & 0 & 0 & 0 \\
\hline & $\mathrm{Al}_{2} \mathrm{O}_{3}$ & 0 & 0 & 0 & 0 & 0 & 0 & 0 & 0 \\
\hline & $\mathrm{Ag} / \mathrm{Al}_{2} \mathrm{O}_{3}$ & 0 & 0 & 11 & 0 & 0 & 4 & 24 & 0 \\
\hline
\end{tabular}

Silver supported catalyst promotes the $\mathrm{NO}$ conversion and $\mathrm{N}_{2}$ yield in the whole temperature range. $\mathrm{NO}_{2}$ emission is lower than the one observed with alumina. In fact, $\mathrm{NO}_{2}$ is not detected at $350^{\circ} \mathrm{C}$ or $450^{\circ} \mathrm{C}$ and reaches a yield of $32 \%$ at $550^{\circ} \mathrm{C}$, compare to $45 \%$ for $\mathrm{Al}_{2} \mathrm{O}_{3}$. On $\mathrm{Ag} / \mathrm{Al}_{2} \mathrm{O}_{3}$ sample, $\mathrm{NH}_{3}$ emission is likewise detected. The higher is the $\mathrm{NH}_{3}$ yield, the higher is the NO conversion. In fact, total NO conversion is achieved at $450^{\circ} \mathrm{C}$, when ammonia yield reaches about $25 \%$. Such emission of ammonia is rarely reported in literature and was discussed in a previous work [23]. 
These first results indicate that $\mathrm{NO}$ oxidation into $\mathrm{NO}_{2}$ plays an important role in the $\mathrm{NO}$ reduction mechanism. The reactivity of the SCR mechanism is complex and specific supplementary tests have been performed in order to understand and highlight the SCR mechanism.

\subsection{Specific tests}

\subsubsection{NO oxidation}

The reactions were carried out with 400ppm NO and $8 \% \mathrm{O}_{2}$ (Table 1) in the presence or not of $167 \mathrm{ppm} \mathrm{H}_{2}$. Dry condition (no water) or addition of $10 \% \mathrm{H}_{2} \mathrm{O}$ was also used for comparison.

\section{$\underline{\text { NO oxidation in absence of } \mathrm{H}_{2}}$}

In absence of $\mathrm{H}_{2}$ and in dry condition (i.e. $\mathrm{NO}$ oxidation conditions presented in Table 1), the oxidation of $\mathrm{NO}$ into $\mathrm{NO}_{2}$ is never observed in the gas phase. On the contrary, on $\mathrm{Al}_{2} \mathrm{O}_{3}, \mathrm{NO}_{2}$ is observed, but only at high temperature $\left(550^{\circ} \mathrm{C}\right)$, and with a low yield $(5 \%)$. No other compounds are detected, namely $\mathrm{N}_{2} \mathrm{O}, \mathrm{NH}_{3}$ or $\mathrm{N}_{2}$. Surprisingly, similar result is obtained with silver supported catalyst $\left(\mathrm{Ag} / \mathrm{Al}_{2} \mathrm{O}_{3}\right.$ sample).

It is reported in literature that NO oxidation starts by an adsorption step on acidic surface sites over $\mathrm{Al}_{2} \mathrm{O}_{3}$ [27-32]. $\mathrm{NO}$ is furthermore oxidized to nitrites species which involve basic oxygen of alumina support, and is thereafter desorbed into $\mathrm{NO}_{2}$. This assumption was confirmed by $\mathrm{O}_{2}$ isotopic exchange experiments (not shown), which show that gas ${ }^{18} \mathrm{O}_{2}$ is exchanged with ${ }^{16} \mathrm{O}_{2}$ of alumina matrix from $500^{\circ} \mathrm{C}$. In presence of $\mathrm{H}_{2} \mathrm{O}$, the water dissociation on Lewis acidbase sites blocks this mechanism, and no $\mathrm{NO}_{2}$ emission is then observed in this condition (NO $+\mathrm{O}_{2}+\mathrm{H}_{2} \mathrm{O}$ ) over alumina in the studied temperature range.

\section{$\underline{\text { NO oxidation in presence of } \mathrm{H}_{2}}$}

As mentioned above, without $\mathrm{H}_{2}$ and $\mathrm{H}_{2} \mathrm{O}$ in the gas mixture $\left(\mathrm{NO}+\mathrm{O}_{2}\right)$, similar $\mathrm{NO}_{2}$ yield is obtained at $550^{\circ} \mathrm{C}$ with alumina or with $\mathrm{Ag} / \mathrm{Al}_{2} \mathrm{O}_{3}$. Silver is then not involved in the $\mathrm{NO}$ oxidation mechanism. If $\mathrm{H}_{2}$ is added to the gas mixture $\left(\mathrm{NO}+\mathrm{O}_{2}+\mathrm{H}_{2}\right)$, no effect of $\mathrm{H}_{2}$ is observed on $\mathrm{Al}_{2} \mathrm{O}_{3}$. On the contrary, $\mathrm{NO}_{2}$ emission is detected from $150^{\circ} \mathrm{C}$ on $\mathrm{Ag} / \mathrm{Al}_{2} \mathrm{O}_{3}$ catalyst (vs. $550^{\circ} \mathrm{C}$ in absence of $\mathrm{H}_{2}$ ) and the $\mathrm{NO}_{2}$ yield reaches about $60 \%$ at $550^{\circ} \mathrm{C}$. Then, hydrogen favors the NO oxidation, but only with silver supported material. No other compound than $\mathrm{NO}_{2}$ is detected (no $\mathrm{N}_{2} \mathrm{O}$ or $\mathrm{NH}_{3}$ ). It is proposed that, even in small amount (167 ppm), hydrogen is able to reduce silver particles, leading to higher oxidation performances. It is also likely that hydrogen favors the desorption of nitrate species adsorbed on silver, giving $\mathrm{NO}_{2}$. Besides, in presence of water $\left(\mathrm{NO}+\mathrm{O}_{2}+\mathrm{H}_{2} \mathrm{O}\right), \mathrm{NO}_{2}$ yield increases up to $20 \%$ at $550^{\circ} \mathrm{C}$ over $\mathrm{Ag} / \mathrm{Al}_{2} \mathrm{O}_{3}$ catalyst, whereas $\mathrm{NO}_{2}$ 
is not emitted on $\mathrm{Al}_{2} \mathrm{O}_{3}$ with these conditions. This result seems to support the assumption of nitrates desorption, since water cannot reduce silver species.

\subsubsection{Investigation on $\mathrm{C}_{2} \mathrm{H}_{5} \mathrm{OH}-\mathrm{SCR}$}

The $\mathrm{C}_{2} \mathrm{H}_{5} \mathrm{OH}$-SCR was studied in detail, with a special attention concerning the thermal decomposition and the catalytic results in regards on simplified reaction.

\section{Thermal decomposition and oxidation of $\mathrm{C}_{2} \mathrm{H}_{5} \mathrm{OH}$}

In thermal condition (without any sample), $\mathrm{C}_{2} \mathrm{H}_{5} \mathrm{OH}$ is not decomposed and does not react with $\mathrm{O}_{2}$ or NO. Nevertheless, if $\mathrm{NO}$ and $\mathrm{O}_{2}$ are both present in the gas mixture (simplified SCR tests, Table 2), a small conversion is observed from $450^{\circ} \mathrm{C}$ and, at $550^{\circ} \mathrm{C}$, the $\mathrm{NO}$ and $\mathrm{C}_{2} \mathrm{H}_{5} \mathrm{OH}$ conversions reach $92 \%$ and $40 \%$, respectively. Similar results are obtained in standard SCR tests. $\mathrm{N}_{2}$ is observed only at $550^{\circ} \mathrm{C}\left(\mathrm{N}_{2}\right.$ yield about $16 \%$ ) whatever the gas mixture (i.e simplified or standard $\mathrm{C}_{2} \mathrm{H}_{5} \mathrm{OH}-\mathrm{SCR}$ ). The following suggested scheme is then proposed:

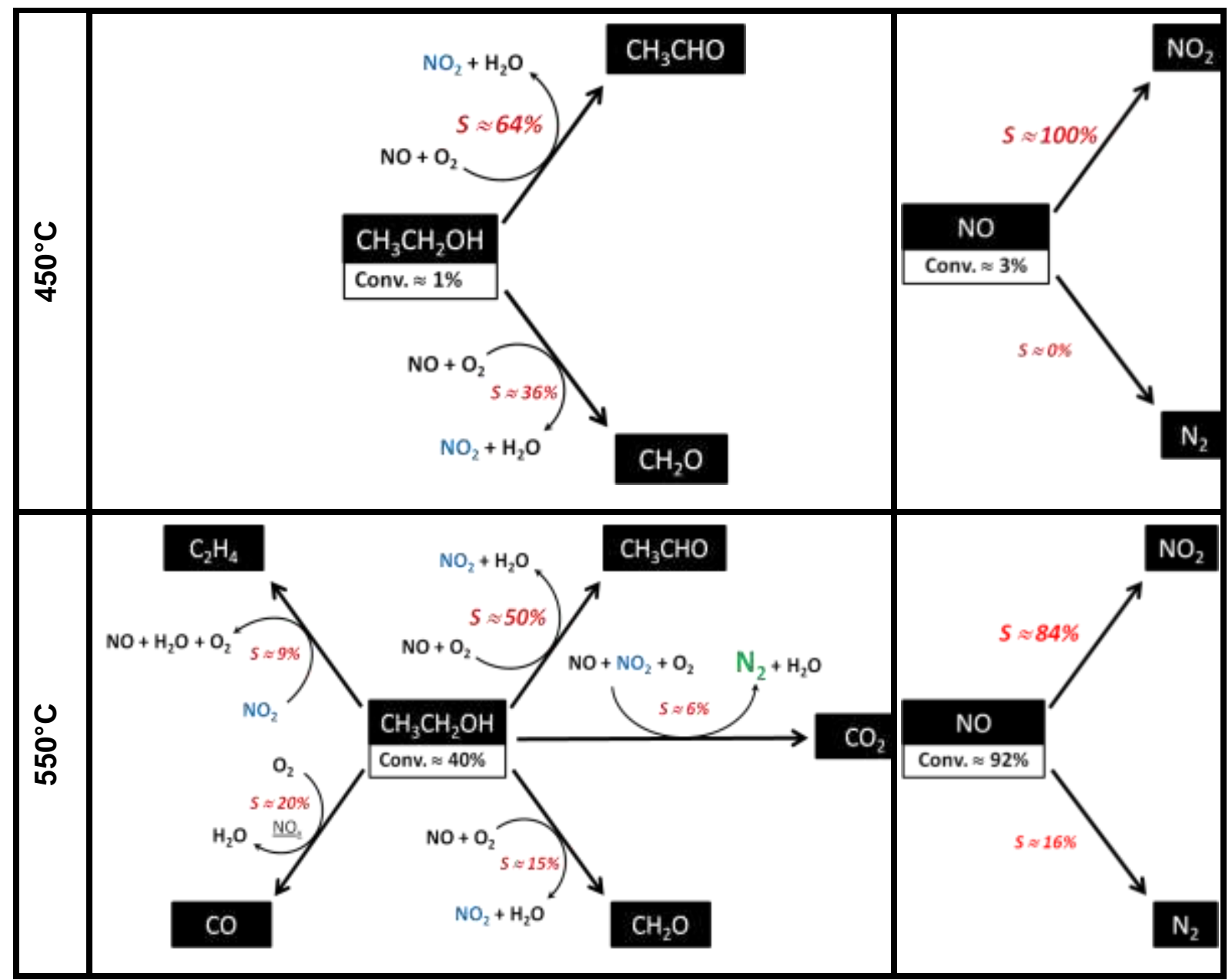

Scheme 1: Reaction mechanism pathway for $\mathrm{C}_{2} \mathrm{H}_{5} \mathrm{OH}$-SCR in thermal condition for $\mathrm{C}_{2} \mathrm{H}_{5} \mathrm{OH}+$ $\mathrm{NO}+\mathrm{O}_{2}$ gas mixture. S: selectivity. 
To conclude, thermal $\mathrm{C}_{2} \mathrm{H}_{5} \mathrm{OH}-\mathrm{SCR}$ reaction is active essentially at high temperature $\left(550^{\circ} \mathrm{C}\right)$, leading to a maximum of about $90 \%$ of NO conversion, with $\mathrm{N}_{2}$ selectivity close to $16 \%$ and an important amount of $\mathrm{NO}_{2}$ detected $(\mathrm{S} \approx 85 \%)$. Ethanol is mainly oxidized into $\mathrm{CH}_{3} \mathrm{CHO}(50 \%$ of selectivity at $550^{\circ} \mathrm{C}$ ), but also into $\mathrm{CO}, \mathrm{CH}_{2} \mathrm{O}, \mathrm{C}_{2} \mathrm{H}_{4}$ and $\mathrm{CO}_{2}$.

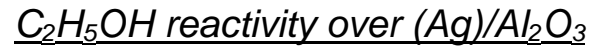

Different results were obtained on $\mathrm{Al}_{2} \mathrm{O}_{3}$ or $\mathrm{Ag} / \mathrm{Al}_{2} \mathrm{O}_{3}$ catalyst. Firstly, ethanol (alone) is decomposed on alumina from $150^{\circ} \mathrm{C}\left(5 \%\right.$ of conversion), and the conversion is total at $350^{\circ} \mathrm{C}$. The main product is ethylene, with a yield of about $85 \%$ in the $350-550^{\circ} \mathrm{C}$ temperature range. Similar results (conversion and selectivity) are obtained on $\mathrm{Ag} / \mathrm{Al}_{2} \mathrm{O}_{3}$. However, addition of $\mathrm{O}_{2}$ in the gas mixture $\left(\mathrm{C}_{2} \mathrm{H}_{5} \mathrm{OH}+\mathrm{O}_{2}\right)$ dramatically modifies the $\mathrm{C}$-compound selectivities between $\mathrm{Al}_{2} \mathrm{O}_{3}$ and $\mathrm{Ag} / \mathrm{Al}_{2} \mathrm{O}_{3}$ catalysts (Table 3).

Table 3: $\mathrm{C}_{2} \mathrm{H}_{5} \mathrm{OH}$ conversion and C-compound yields for $\left(\mathrm{C}_{2} \mathrm{H}_{5} \mathrm{OH}+\mathrm{O}_{2}\right)$ and $\left(\mathrm{C}_{2} \mathrm{H}_{5} \mathrm{OH}+\mathrm{NO}+\right.$ $\mathrm{O}_{2}$ ) reaction in thermal condition, with $\mathrm{Al}_{2} \mathrm{O}_{3}$ or with $\mathrm{Ag} / \mathrm{Al}_{2} \mathrm{O}_{3}$.

\begin{tabular}{|c|c|c|c|c|c|c|c|c|c|}
\hline \multirow{2}{*}{\multicolumn{2}{|c|}{$\begin{array}{c}\text { Reaction } \\
\text { Temperature }\left({ }^{\circ} \mathrm{C}\right)\end{array}$}} & \multicolumn{4}{|c|}{$\mathrm{C}_{2} \mathrm{H}_{5} \mathrm{OH}+\mathrm{O}_{2}$} & \multicolumn{4}{|c|}{$\mathrm{C}_{2} \mathrm{H}_{5} \mathrm{OH}+\mathrm{NO}+\mathrm{O}_{2}$} \\
\hline & & $250^{\circ} \mathrm{C}$ & $350^{\circ} \mathrm{C}$ & $450^{\circ} \mathrm{C}$ & $550^{\circ} \mathrm{C}$ & $250^{\circ} \mathrm{C}$ & $350^{\circ} \mathrm{C}$ & $450^{\circ} \mathrm{C}$ & $550^{\circ} \mathrm{C}$ \\
\hline \multirow{3}{*}{$\begin{array}{l}\mathrm{C}_{2} \mathrm{H}_{5} \mathrm{OH} \\
\text { conv. (\%) }\end{array}$} & Thermal & 0 & 0 & 0 & 0 & 0 & 0 & 1 & 40 \\
\hline & $\mathrm{Al}_{2} \mathrm{O}_{3}$ & 48 & 100 & 100 & 100 & 38 & 95 & 100 & 100 \\
\hline & $\mathrm{Ag} / \mathrm{Al}_{2} \mathrm{O}_{3}$ & 35 & 100 & 100 & 100 & 46 & 100 & 100 & 100 \\
\hline \multirow{3}{*}{$\begin{array}{l}\mathrm{CH}_{3} \mathrm{CHO} \\
\text { yield (\%) }\end{array}$} & Thermal & 0 & 0 & 0 & 0 & 0 & 0 & $<1$ & 20 \\
\hline & $\mathrm{Al}_{2} \mathrm{O}_{3}$ & 2 & 2 & 0 & 0 & 4 & 21 & 1 & 0 \\
\hline & $\mathrm{Ag} / \mathrm{Al}_{2} \mathrm{O}_{3}$ & 31 & 61 & 0 & 0 & 38 & 25 & 0 & 0 \\
\hline \multirow{3}{*}{$\begin{array}{c}\mathrm{C}_{2} \mathrm{H}_{4} \\
\text { yield (\%) }\end{array}$} & Thermal & 0 & 0 & 0 & 0 & 0 & 0 & 0 & 4 \\
\hline & $\mathrm{Al}_{2} \mathrm{O}_{3}$ & 12 & 81 & 85 & 73 & 7 & 17 & 53 & 33 \\
\hline & $\mathrm{Ag} / \mathrm{Al}_{2} \mathrm{O}_{3}$ & 0 & 2 & 17 & 39 & 0 & 1 & 10 & 0 \\
\hline \multirow{3}{*}{$\begin{array}{c}\mathrm{CO}_{2} \\
\text { yield (\%) }\end{array}$} & Thermal & 0 & 0 & 0 & 0 & 0 & 0 & 0 & 2 \\
\hline & $\mathrm{Al}_{2} \mathrm{O}_{3}$ & 34 & 16 & 13 & 21 & 28 & 46 & 25 & 35 \\
\hline & $\mathrm{Ag} / \mathrm{Al}_{2} \mathrm{O}_{3}$ & 3 & 33 & 64 & 46 & 5 & 59 & 67 & 94 \\
\hline
\end{tabular}

On alumina, no effect of $\mathrm{O}_{2}$ is observed on the ethanol conversion, similar catalytic results are observed with $\mathrm{C}_{2} \mathrm{H}_{5} \mathrm{OH}$ alone or $\mathrm{C}_{2} \mathrm{H}_{5} \mathrm{OH}+\mathrm{O}_{2}$ (Table 3). In presence of $\mathrm{NO}+\mathrm{O}_{2}$ the selectivity is strongly modified and $\mathrm{CH}_{3} \mathrm{CHO}$ yield is greatly enhanced, especially at $350^{\circ} \mathrm{C}$. Acetaldehyde yield then reaches $21 \%$, compare to $2 \%$ in absence of $\mathrm{NO}$ in the gas mixture. In parallel, $\mathrm{N}_{2}$ conversion over alumina is $2 \%$ and $35 \%$ at $250^{\circ} \mathrm{C}$ and $350^{\circ} \mathrm{C}$, respectively (results reported in Table 2). Thus, it seems that $\mathrm{NO}+\mathrm{O}_{2}$ reacts with $\mathrm{C}_{2} \mathrm{H}_{5} \mathrm{OH}$ to produce both $\mathrm{N}_{2}$ and $\mathrm{CH}_{3} \mathrm{CHO}$ on 
alumina active sites. This way is assumed to be the first reaction path to produce $\mathrm{N}_{2}$ at low temperature on alumina active sites.

Using $\mathrm{Ag} / \mathrm{Al}_{2} \mathrm{O}_{3}$, ethanol oxidation $\left(\mathrm{C}_{2} \mathrm{H}_{5} \mathrm{OH}+\mathrm{O}_{2}\right)$ leads mainly to acetaldehyde at low temperature $\left(61 \%\right.$ of $\mathrm{CH}_{3} \mathrm{CHO}$ yield at $\left.350^{\circ} \mathrm{C}\right)$, whereas $\mathrm{CO}_{2}$ and $\mathrm{C}_{2} \mathrm{H}_{4}$ are the major products at $450^{\circ} \mathrm{C}$ and $550^{\circ} \mathrm{C}$, with ethylene yields of $17 \%$ and $39 \%$, respectively. Ethylene is no more observed at $550^{\circ} \mathrm{C}$, whereas a yield of $33 \%$ is obtained with alumina without silver. When NO is added to the gas mixture, $\mathrm{CH}_{3} \mathrm{CHO}$ yield increases from $30 \%\left(\mathrm{C}_{2} \mathrm{H}_{5} \mathrm{OH}+\mathrm{O}_{2}\right)$ to $40 \%$ $\left(\mathrm{C}_{2} \mathrm{H}_{5} \mathrm{OH}+\mathrm{NO}+\mathrm{O}_{2}\right)$ at $250^{\circ} \mathrm{C}$ (Table 3$)$. This higher acetaldehyde formation is directly correlated with the ethanol conversion which is $10 \%$ higher in presence of $\mathrm{NO}$ with $\mathrm{Ag} / \mathrm{Al}_{2} \mathrm{O}_{3}$ catalyst. Note that using acetaldehyde (simplified $\mathrm{CH}_{3} \mathrm{CHO}-\mathrm{SCR}$ tests, Table 2), $\mathrm{NO}$ conversion is about $8 \%$ at $250^{\circ} \mathrm{C}$, but mainly into $\mathrm{NO}_{2}$. Finally, acetaldehyde reactivity in $\mathrm{NO}$ reduction is a key parameter in $\mathrm{C}_{2} \mathrm{H}_{5} \mathrm{OH}-\mathrm{SCR}$, and investigation of $\mathrm{CH}_{3} \mathrm{CHO}$-SCR behaviors is presented thereafter.

\subsubsection{Investigation on $\mathrm{CH}_{3} \mathrm{CHO}-\mathrm{SCR}$}

It was showed previously that acetaldehyde is as an active reducer in standard SCR condition (Figure 2C). Besides, during the $\mathrm{C}_{2} \mathrm{H}_{5} \mathrm{OH}-\mathrm{SCR}$ experiments on silver supported material, $\mathrm{CH}_{3} \mathrm{CHO}$ is the main by-product, obtained by dehydrogenation. Thus reactivity of $\mathrm{CH}_{3} \mathrm{CHO}$ was carefully studied.

\section{Thermal decomposition and reaction of $\mathrm{CH}_{3} \mathrm{CHO}$}

It was firstly checked that acetaldehyde is not thermally decomposed $\left(\mathrm{CH}_{3} \mathrm{CHO}\right.$ alone $)$ and it does not react with $\mathrm{NO}\left(\mathrm{CH}_{3} \mathrm{CHO}+\mathrm{NO}\right)$ from $150^{\circ} \mathrm{C}$ to $550^{\circ} \mathrm{C}$. However, in presence of both $\mathrm{NO}+\mathrm{O}_{2}\left(\mathrm{CH}_{3} \mathrm{CHO}+\mathrm{NO}+\mathrm{O}_{2}\right)$ a low acetaldehyde conversion (2\%) with $\mathrm{NO}_{2}$ production (3\%) is observed starting from $350^{\circ} \mathrm{C}$. It is important to note that the thermal oxidation of $\mathrm{NO}$ to $\mathrm{NO}_{2}$ (without reducer, part 3.3.1) is not observed. Then, at $350^{\circ} \mathrm{C}, \mathrm{CH}_{3} \mathrm{CHO}$ reacts with both NO and $\mathrm{O}_{2}$ to produce $\mathrm{NO}_{2}$, formaldehyde $\left(\mathrm{CH}_{2} \mathrm{O}\right)$ and $\mathrm{CO}$, according to the following reactions:

$$
\begin{aligned}
& \mathrm{CH}_{3} \mathrm{CHO}+2 \mathrm{NO}+3 / 2 \mathrm{O}_{2} \rightarrow 2 \mathrm{CH}_{2} \mathrm{O}+2 \mathrm{NO}_{2} \\
& \mathrm{CH}_{3} \mathrm{CHO}+2 \mathrm{NO}+5 / 2 \mathrm{O}_{2} \rightarrow 2 \mathrm{CO}+2 \mathrm{NO}_{2}+2 \mathrm{H}_{2} \mathrm{O}
\end{aligned}
$$

The thermal conversion of $\mathrm{CH}_{3} \mathrm{CHO}$ increases with the temperature, to $9 \%$ at $450^{\circ} \mathrm{C}$. Besides, at $450^{\circ} \mathrm{C}, \mathrm{N}_{2}$ formation is also observed according to reaction (3):

$$
\mathrm{CH}_{3} \mathrm{CHO}+\mathrm{NO}+\mathrm{NO}_{2}+\mathrm{O}_{2} \rightarrow 2 \mathrm{CO}_{2}+\mathrm{N}_{2}+2 \mathrm{H}_{2} \mathrm{O}
$$

At higher temperature $\left(550^{\circ} \mathrm{C}\right)$, the thermal conversion of acetaldehyde reaches $63 \%$. Contrary to results obtained at $350^{\circ} \mathrm{C}$ and $450^{\circ} \mathrm{C}, \mathrm{CH}_{3} \mathrm{CHO}$ can be directly oxidized by $\mathrm{O}_{2}$ at $550^{\circ} \mathrm{C}$ $\left(\mathrm{CH}_{3} \mathrm{CHO}+\mathrm{O}_{2}\right)$, mainly into formaldehyde and $\mathrm{CO}$. 
Based on the whole of results, the following reaction pathway for $\mathrm{CH}_{3} \mathrm{CHO}-\mathrm{SCR}$ in thermal condition is proposed:

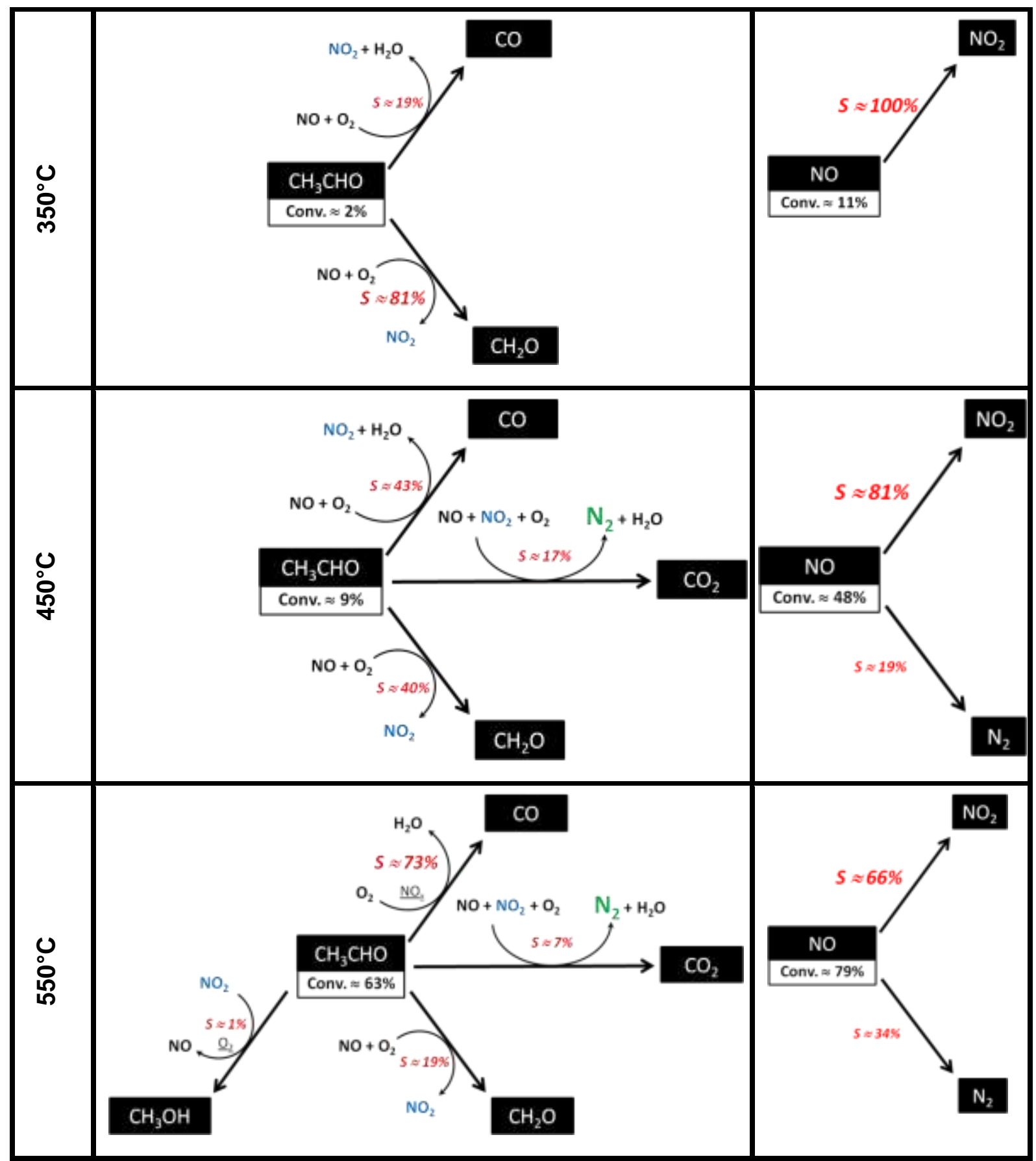

Scheme 2: Reaction mechanism pathway for $\mathrm{CH}_{3} \mathrm{CHO}$-SCR in thermal condition for $\mathrm{CH}_{3} \mathrm{CHO}$ $+\mathrm{NO}+\mathrm{O}_{2}$ gas mixture.

\section{Catalytic decomposition and oxidation of $\mathrm{CH}_{3} \mathrm{CHO}$}

Acetaldehyde decomposition or oxidation (Table 1) was firstly studied over alumina and then over $\mathrm{Ag} / \mathrm{Al}_{2} \mathrm{O}_{3}$. On $\mathrm{Al}_{2} \mathrm{O}_{3}$, the $\mathrm{CH}_{3} \mathrm{CHO}$ conversion starts from $300^{\circ} \mathrm{C}$, and it is total at $550^{\circ} \mathrm{C}$, 
with or without $\mathrm{O}_{2}$ in the gas mixture. However, selectivity depends on the presence of $\mathrm{O}_{2}$. Indeed, without oxygen, an important amount of $\mathrm{CO}$ is observed. With $\mathrm{O}_{2}$, the main oxidative compound detected at $550^{\circ} \mathrm{C}$ is $\mathrm{CO}_{2}$. Addition of silver to alumina $\left(\mathrm{Ag} / \mathrm{Al}_{2} \mathrm{O}_{3}\right)$ enhances the acetaldehyde decomposition $\left(\mathrm{CH}_{3} \mathrm{CHO}\right.$ alone) from $75 \%$ to $100 \%$ at $450^{\circ} \mathrm{C}$, and favors the $\mathrm{CO}_{2}$ formation at $550^{\circ} \mathrm{C}$.

Catalytic reduction of $\mathrm{NO}$ with $\mathrm{CH}_{3} \mathrm{CHO}\left(\mathrm{CH}_{3} \mathrm{CHO}+\mathrm{NO}+\mathrm{O}_{2}\right)$, effect of water

Catalytic results for the $\left(\mathrm{CH}_{3} \mathrm{CHO}+\mathrm{NO}+\mathrm{O}_{2}\right)$ reaction, mentioned as simplified $\mathrm{CH}_{3} \mathrm{CHO}-\mathrm{SCR}$ tests in Table 1, was previously presented in Table 2 for $\mathrm{Ag} / \mathrm{Al}_{2} \mathrm{O}_{3}$. Conversions of $\mathrm{CH}_{3} \mathrm{CHO}$ and $\mathrm{NO}$ obtained over $\mathrm{Al}_{2} \mathrm{O}_{3}$ and $\mathrm{Ag} / \mathrm{Al}_{2} \mathrm{O}_{3}$ are compared in Figures $3 \mathrm{~A}$ and $3 \mathrm{~B}$, and the effect of $\mathrm{H}_{2} \mathrm{O}$ is depicted in Figure $3 \mathrm{C}$.
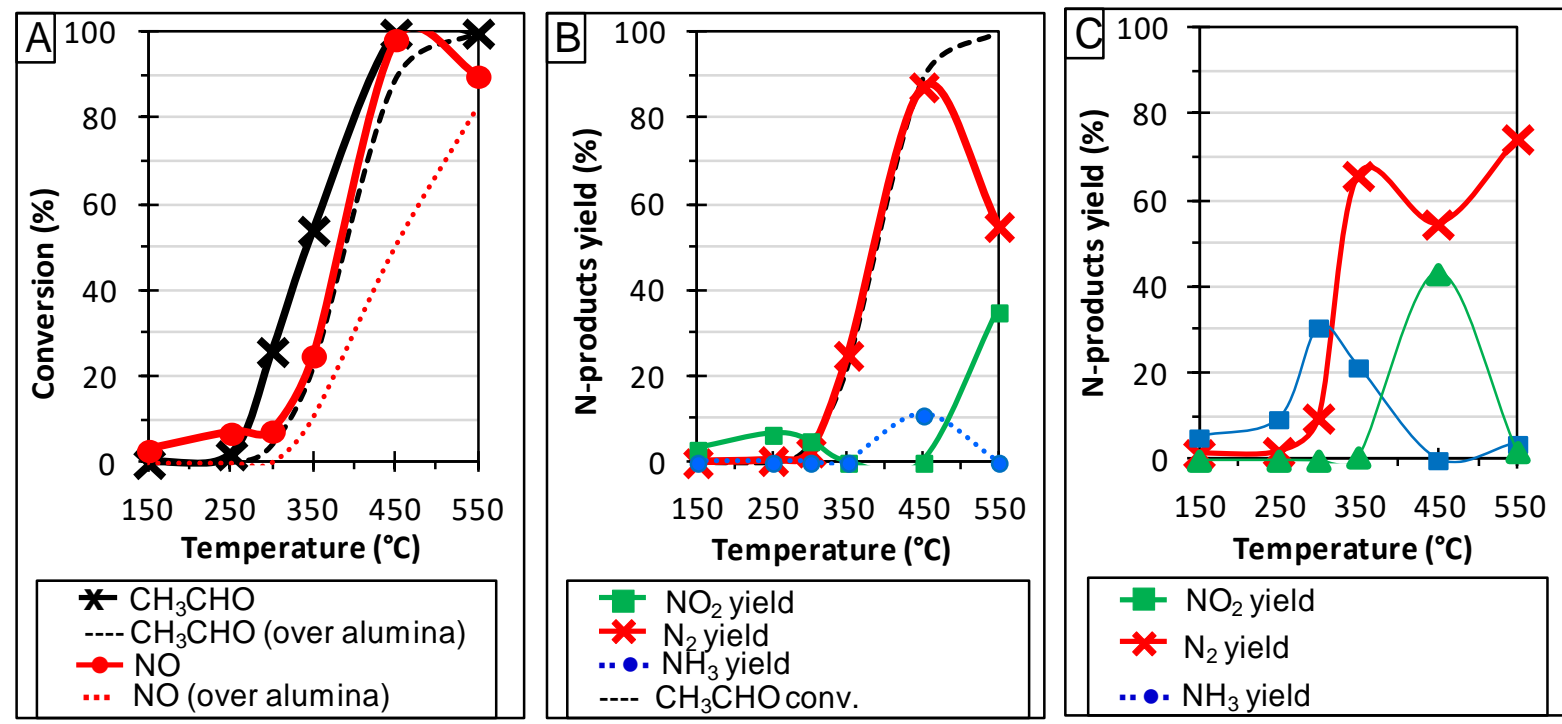

Figure 3: Simplified $\mathrm{CH}_{3} \mathrm{CHO}-\mathrm{SCR}$ tests on $\mathrm{Ag} / \mathrm{Al}_{2} \mathrm{O}_{3}$. (A) $\mathrm{CH}_{3} \mathrm{CHO}$ and $\mathrm{NO}$ conversion. (B) Ncompound yields; (C) Effect of water: N-compound yields for $\left(\mathrm{NO}+\mathrm{O}_{2}+\mathrm{H}_{2} \mathrm{O}\right)$ condition. Catalytic results obtained over $\mathrm{Al}_{2} \mathrm{O}_{3}$ are plotted in dotted line $\left(\mathrm{CH}_{3} \mathrm{CHO}\right.$ yields in Fig $\mathrm{B}$ and $\left.\mathrm{C}\right)$. Gas mixture: 1200 ppm $\mathrm{CH}_{3} \mathrm{CHO}, 400$ ppm NO, $8 \% \mathrm{O}_{2},\left(10 \% \mathrm{H}_{2} \mathrm{O}\right)$ balanced with $\mathrm{N}_{2}$.

As expected, $\mathrm{CH}_{3} \mathrm{CHO}$ and $\mathrm{NO}$ conversions are enhanced with $\mathrm{Ag} / \mathrm{Al}_{2} \mathrm{O}_{3}$ catalyst, compare to $\mathrm{Al}_{2} \mathrm{O}_{3}$. Figure $3 \mathrm{~B}$ also reveals that the $\mathrm{N}_{2}$ yield observed with $\mathrm{Ag} / \mathrm{Al}_{2} \mathrm{O}_{3}$ catalyst is correlated with the $\mathrm{CH}_{3} \mathrm{CHO}$ conversion obtained with alumina (in dotted line), in a large temperature range $\left(150-450^{\circ} \mathrm{C}\right)$. This result seems to indicate that the $\mathrm{N}_{2}$ formation in $\mathrm{CH}_{3} \mathrm{CHO}-\mathrm{SCR}$ is linked to the activation of acetaldehyde over the alumina support.

Addition of water in the feed stream $\left(\mathrm{CH}_{3} \mathrm{CHO}+\mathrm{NO}+\mathrm{O}_{2}+\mathrm{H}_{2} \mathrm{O}\right.$ mixture $)$ significantly changes the $\mathrm{N}$-compound yields (Figure $3 \mathrm{C}$ ). The $\mathrm{N}_{2}$ yield is then improved in the low temperature range. For instance, at $350^{\circ} \mathrm{C}$, the $\mathrm{N}_{2}$ yield reaches $67 \%$, compared to $22 \%$ without water. In opposition, the $\mathrm{N}_{2}$ yield is strongly decreased at $450^{\circ} \mathrm{C}$, which is correlated with the enhancement of the ammonia yield with water. Another important point is that $\mathrm{NO}_{2}$ yield is also 
enhanced with $\mathrm{H}_{2} \mathrm{O}$ around $300^{\circ} \mathrm{C}$, from $7 \%$ to $30 \%$ at this temperature. Besides, the $\mathrm{N}_{2}$ yield is no more correlated with the $\mathrm{CH}_{3} \mathrm{CHO}$ conversion obtained with alumina (in dotted line, Figure $3 \mathrm{C}$ ), as it was reported in absence of $\mathrm{H}_{2} \mathrm{O}$ in the gas mixture (Figure 3B).

\subsection{Highlights on the EtOH-SCR mechanism with $\mathrm{Ag} / \mathrm{Al}_{2} \mathrm{O}_{3}$}

\subsubsection{Low temperature limitation in $\mathrm{EtOH}-\mathrm{SCR}$ with $\mathrm{Ag} / \mathrm{Al}_{2} \mathrm{O}_{3}\left(\mathrm{~T} \leq 300^{\circ} \mathrm{C}\right)$}

At $250^{\circ} \mathrm{C}$, the presence of $\mathrm{NO}$ in the gas mixture increases the ethanol conversion on $\mathrm{Ag} / \mathrm{Al}_{2} \mathrm{O}_{3}$, from $35 \%$ to $46 \%$ (Table 3). In fact, in absence of $\mathrm{NO}$, a higher $\mathrm{C}_{2} \mathrm{H}_{5} \mathrm{OH}$ conversion is observed on $\mathrm{Al}_{2} \mathrm{O}_{3}$ support than on $\mathrm{Ag} / \mathrm{Al}_{2} \mathrm{O}_{3}$ catalyst. Besides, $\mathrm{NO}$ conversion is effective at $250^{\circ} \mathrm{C}$ on $\mathrm{Ag} / \mathrm{Al}_{2} \mathrm{O}_{3}(28 \%$, Table 2), but is very low on alumina (3\%). At this temperature, Table 3 reveals that on $\mathrm{Ag} / \mathrm{Al}_{2} \mathrm{O}_{3}$ catalyst, ethanol activation leads mainly to the formation of $\mathrm{CH}_{3} \mathrm{CHO}$ (yield about $38 \%$ ) when $\mathrm{NO}$ is present on the gas mixture. In absence of $\mathrm{NO}\left(\mathrm{C}_{2} \mathrm{H}_{5} \mathrm{OH}+\mathrm{O}_{2}\right)$, $\mathrm{CH}_{3} \mathrm{CHO}$ yield drops to $31 \%$. Note that acetaldehyde is produced in very low amount on alumina $\left(\mathrm{C}_{2} \mathrm{H}_{5} \mathrm{OH}+\mathrm{O}_{2}\right.$ mixture $)$. Thus on $\mathrm{Ag} / \mathrm{Al}_{2} \mathrm{O}_{3}$ catalyst, it appears that the dehydrogenation reaction (4), leading also to the formation of hydrogen, becomes faster than the dehydration one.

$$
\mathrm{C}_{2} \mathrm{H}_{5} \mathrm{OH} \rightarrow \mathrm{CH}_{3} \mathrm{CHO}+\mathrm{H}_{2}
$$

It was previously reported in section 3.3.1 that $\mathrm{Ag} / \mathrm{Al}_{2} \mathrm{O}_{3}$ and $\mathrm{Al}_{2} \mathrm{O}_{3}$ samples act differently in presence of $\mathrm{H}_{2}$, especially for the $\mathrm{NO}$ oxidation reaction. In fact the presence of a low concentration of $\mathrm{H}_{2}\left(167 \mathrm{ppm}\right.$,) enables the oxidation of $\mathrm{NO}$ into $\mathrm{NO}_{2}$ on $\mathrm{Ag} / \mathrm{Al}_{2} \mathrm{O}_{3}$ at low temperature (starting from $150^{\circ} \mathrm{C}$ ). Without hydrogen in the gas mixture, $\mathrm{NO}_{2}$ is not observed at low temperature $\left(\mathrm{T} \leq 300^{\circ} \mathrm{C}\right)$. Then, the use of $\mathrm{C}_{2} \mathrm{H}_{5} \mathrm{OH}$ leads to the formation of $\mathrm{NO}_{2}$ at low temperature (i.e $250^{\circ} \mathrm{C}$ ) on $\mathrm{Ag} / \mathrm{Al}_{2} \mathrm{O}_{3}$ (yield about $14 \%$, Table 2 ).

It is thus assumed that the $\mathrm{NO}_{2}$ formation is the rate-determining step in $\mathrm{N}_{2}$ formation. In fact, based on the work of Sachtler et al. [22], it is proposed that the first reaction step of NO oxidation into $\mathrm{NO}_{2}$ leads to the formation of adsorbed nitrates species at low temperature. As reported in literature [30,33], $\mathrm{NO}_{2}$ adsorption on alumina support leads to the formation of three kinds of nitrate species (bridging, monodentate and bidentate). The $\mathrm{C}_{2} \mathrm{H}_{5} \mathrm{OH}$-SCR reaction is thereafter limited by the low reactivity between adsorbed nitrates and ethanol. The deduced $\mathrm{N}_{2}$ formation at $\mathrm{T}<300^{\circ} \mathrm{C}$ may be due to few active nitrite species [34].

In fact, nitrites are reported to be very reactive but formed with a very low extent over alumina [34]. Over alumina, $\mathrm{NO}_{2}$ is much more active than $\mathrm{NO}$ [26], especially for $\mathrm{T}>300^{\circ} \mathrm{C}$. At lower temperature, nitrates are too strongly adsorbed $[28,35,36]$, but addion of $\mathrm{H}_{2}$ allows the increase of the low temperature activity due to the nitrates reduction into highly active nitrites $[37,38,39]$ 


\subsubsection{High temperature mechanism}

A comparative study of the effect of water over $\mathrm{Ag} / \mathrm{Al}_{2} \mathrm{O}_{3}$ catalyst is presented in Figure 4 for the $\mathrm{C}_{2} \mathrm{H}_{5} \mathrm{OH}$-SCR and $\mathrm{CH}_{3} \mathrm{CHO}-\mathrm{SCR}$ tests in simplified condition (reducer $+\mathrm{NO}+\mathrm{O}_{2}$ ). It appears that the profile distribution of $\mathrm{N}$-compound is quite similar whatever the reducer (ethanol or acetaldehyde, Figure $4 \mathrm{~A}$ and $4 \mathrm{C}$ ). In fact, for both reducers, the maximum $\mathrm{N}_{2}$ yield is obtained at $450^{\circ} \mathrm{C}$, at about $75 \%$ and $88 \%$ for $\mathrm{C}_{2} \mathrm{H}_{5} \mathrm{OH}-\mathrm{SCR}$ and $\mathrm{CH}_{3} \mathrm{CHO}-\mathrm{SCR}$ tests, respectively. Total NOx conversion is achieved in both cases and the lower $\mathrm{N}_{2}$ yield obtained with ethanol as reducer is associated with the higher ammonia emission. The presence of water (Figure 4B and 4D) increases the ammonia yield with still a maximum at $450^{\circ} \mathrm{C}$. As a consequence, the $\mathrm{N}_{2}$ yield at this temperature is strongly decreased and maximum $\mathrm{N}_{2}$ yield is then obtained at $350^{\circ} \mathrm{C}$. $\mathrm{NO}_{2}$ emission in the low temperature range is also favored if $\mathrm{H}_{2} \mathrm{O}$ is introduced in the feed stream.
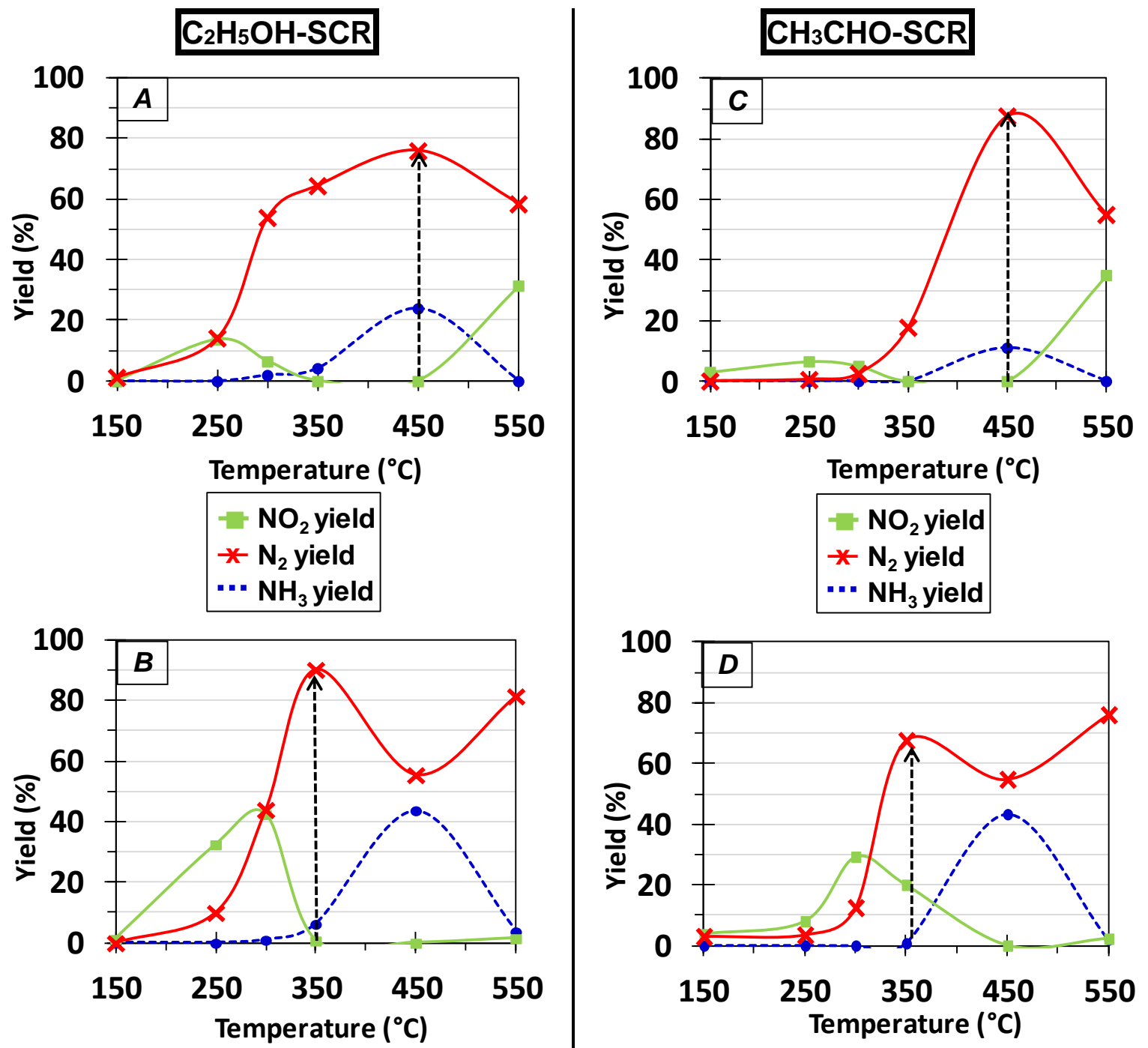

Figure 4: N-compound yields for $\mathrm{C}_{2} \mathrm{H}_{5} \mathrm{OH}$-SCR (A) and $\mathrm{CH}_{3} \mathrm{CHO}-\mathrm{SCR}(\mathrm{C})$ tests in simplified condition over $\mathrm{Ag} / \mathrm{Al}_{2} \mathrm{O}_{3}$ catalyst. Effect of water on $\mathrm{C}_{2} \mathrm{H}_{5} \mathrm{OH}-\mathrm{SCR}$ (B) and $\mathrm{CH}_{3} \mathrm{CHO}$-SCR (D). 
Ammonia formation mechanism is well established in literature $[18,40]$, it involves the hydrolysis of $-\mathrm{NCO}$ species to form $\mathrm{NH}_{3}$. The formation of $-\mathrm{NCO}$ species has been observed in numerous papers over $\mathrm{Ag} / \mathrm{Al}_{2} \mathrm{O}_{3}$ catalysts when high $\mathrm{NOx}$ reduction efficiency is achieved $[40,41]$. It is proposed that $-\mathrm{NCO}$ species are formed by reaction between acetate species (adsorbed acetaldehyde) and adsorbed nitrites/nitrates species. Ammonia can thereafter react with $\mathrm{NO}_{2}$ to form ammonium nitrite. Ammonium nitrite is then decomposed into $\mathrm{H}_{2} \mathrm{O}$ and $\mathrm{N}_{2}$. Isocyanate ions also react with $\mathrm{O}_{2}$ but this reaction is slower than that of -NCO with water, which leads to ammonia formation [17]. Since no $\mathrm{NH}_{3}$ is emitted on $\mathrm{Al}_{2} \mathrm{O}_{3}$ support, -NCO bridged with silver cluster and coordinatively unsaturated sites was recently proposed by Thibaut-Starzik et al.[42]. Finally, reaction pathway for EtOH-SCR is summarized in scheme 4. At low temperature, around $250^{\circ} \mathrm{C}$, the $\mathrm{N}_{2}$ formation is virtually nil with acetaldehyde whereas acetaldehyde is observed together with $\mathrm{N}_{2}$ using ethanol as introduced reducer. In addition, $\mathrm{N}_{2}$ is observed only if $\mathrm{O}_{2}$ is introduced, suggesting that $\mathrm{NO}_{2}$ are the reactive species.

At higher temperature, the $\mathrm{CH}_{3} \mathrm{CHO}+\mathrm{NO}+\mathrm{O}_{2}$ reaction can occur over alumina, without silver. However, silver is supposed to favor -NCO species formation, which explains the enhancement of the nitrogen formation. However, if the $\left(\mathrm{NO}_{\mathrm{x}} /\right.$ isocyanate species) ratio is unbalanced with too many -NCO species, ammonia emission is observed.

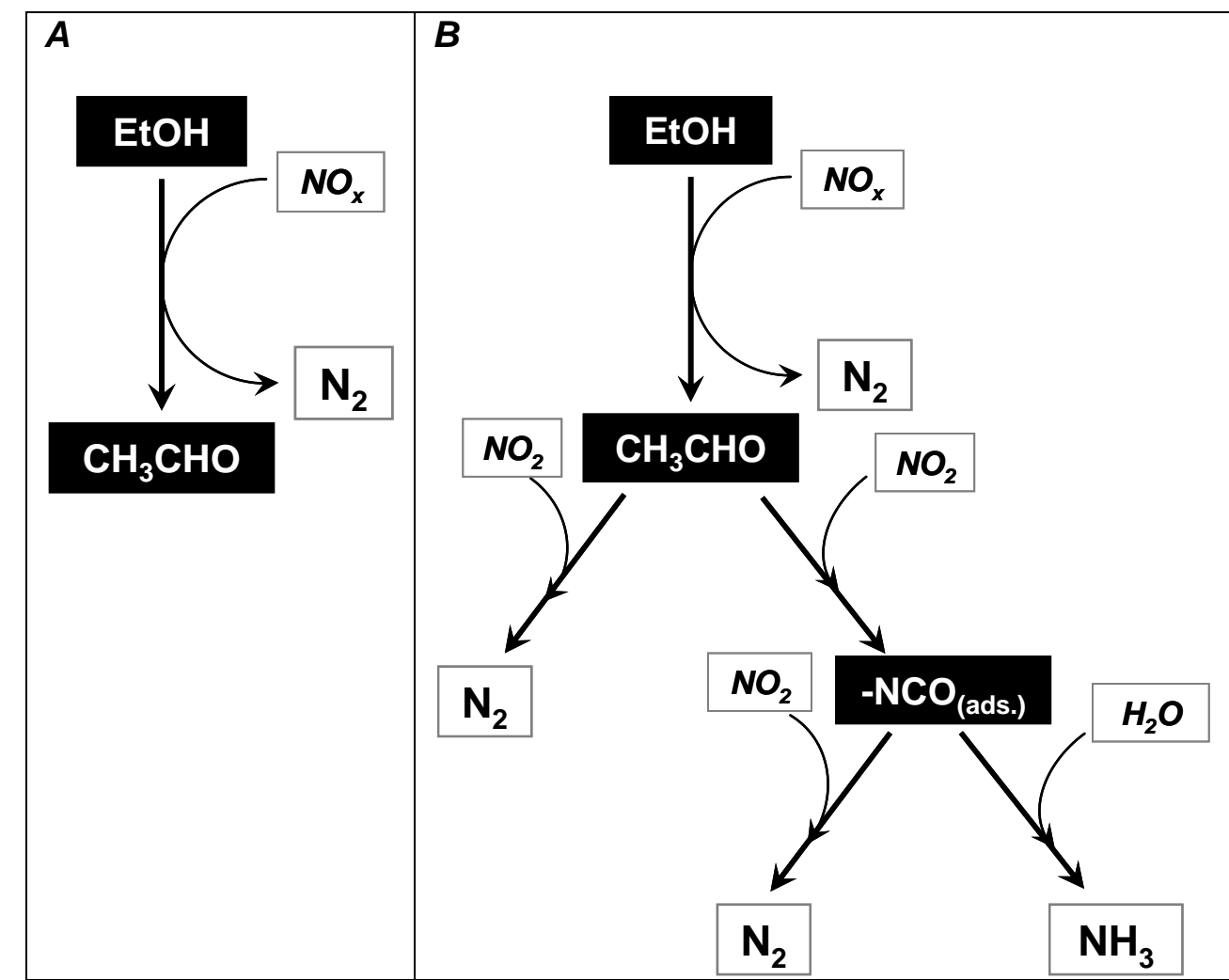

Scheme 4: Proposed reaction pathway for $\mathrm{EtOH}-\mathrm{SCR}$ at $(\mathrm{A})$ low temperature $\left(\mathrm{T} \leq 300^{\circ} \mathrm{C}\right)$ and (B) high temperature $\left(T \geq 300^{\circ} \mathrm{C}\right)$ 


\section{Conclusion}

The mechanism of the $\mathrm{NOx} \mathrm{SCR}$ with ethanol over $\mathrm{Ag} / \mathrm{Al}_{2} \mathrm{O}_{3}$ catalysts was already extensively studied and a global overview is proposed. However, some parameters were not evidenced, such as the test temperature or the roles of the gas phase reactions and alumina support. In this study, we tried to understand the reaction mechanism toward these parameters. During the $\mathrm{C}_{2} \mathrm{H}_{5} \mathrm{OH}$-SCR test, $\mathrm{CO}, \mathrm{C}_{2} \mathrm{H}_{4}$ and $\mathrm{CH}_{3} \mathrm{CHO}$ are also emitted. $\mathrm{CO}$ is not active for the NOx reduction, and $\mathrm{CO}_{2}$ is observed only with $\mathrm{Ag} / \mathrm{Al}_{2} \mathrm{O}_{3}$ and at high temperature $\left(550^{\circ} \mathrm{C}\right)$. Ethylene is able to reduce $\mathrm{NOx}$ into $\mathrm{N}_{2}$ only at $550^{\circ} \mathrm{C}$ over alumina with a limited impact of silver. Ethanol is activated at low temperature over alumina $\left(T \leq 300^{\circ} \mathrm{C}\right)$ but $\mathrm{N}_{2}$ is obtained only with $\mathrm{Ag} / \mathrm{Al}_{2} \mathrm{O}_{3}$ and with $\mathrm{NO}$ and $\mathrm{O}_{2}$ in the feed stream. In fact, $\mathrm{Ag}$ allows $\mathrm{NO}_{2}$ formation from $150^{\circ} \mathrm{C}$. Acetaldehyde is also observed as a product in this low temperature range. At higher temperature $\mathrm{CH}_{3} \mathrm{CHO}$ is an effective $\mathrm{NOx}$ reducer over $\mathrm{Al}_{2} \mathrm{O}_{3}$. It is demonstrated that alumina active sites are involved in the $\mathrm{NO}_{2}$ reduction with $\mathrm{CH}_{3} \mathrm{CHO}$ leading to a possible $\mathrm{NOx}$ reduction pathway to $\mathrm{N}_{2}$. However, silver is supposed to favor -NCO species formation, which explains the enhancement of the nitrogen formation and ammonia emission.

\section{Acknowledgments}

The Authors thank the French Ministry of Economy, Finance and Industry for its financial support (FUI contract $n^{\circ} 072906511$ REDNOx)

\section{References}

[1] Epling WS, Campbell LE, Yezeerets A, Currier NW, Parks JE (2004) Catal Rev 46:163-245

[2] Sedlmair C, Seshan K, Jentys A, Lercher JA (2002) Catal Today 75:413-419

[3] Corbos EC, Courtois X, Bion N, Marecot P, Duprez D (2008) Appl Catal B 80:62-71

[4] Li J, Theis J, Chun W, Goralski C, Kudla R, Ura J, Watkins W, Chattha M, Hurley R (2001) SAE Technical Paper 2001-01-2503

[5] Uy D, O’Neill AE, Li J, Watkins WHL (2004) Top Catal 95:191-201

[6] Casapu M, Grunwaldt JD, Maciejewski M, Wittrock M, Göbel U, Baiker A (2006) Appl Catal B 63:232242

[7] Le Phuc N, Courtois X, Can F, Royer S, Marecot P, Duprez D (2011) Appl Catal B 102:353-361

[8] Corbos EC, Haneda M, Courtois X, Marecot P, Duprez D, Hamada H (2009) Appl Catal A 365:187193

[9] Konsolakis M, Yentekakis IV (2001) J Catal 198:142-150

[10] Cordoba LF, Sachtler WMH, de Correa CM(2005) Appl Catal B 56:269-277

[11] Maunula T, Ahola J, Hamada H (2000) Appl Catal B 26:173-192

[12] Tran D, Aardahl CL, Rappe KG, Park PW, Boyer CL (2004) Appl Catal B 48:155-164

[13] Haj KO, Ziyade S, Ziyad M, Garin F(2002) Appl Catal B 37:49-62

[14] Cant NW, Liu IOY (2000) Catal Today 63:133-146 
[15] Zuzaniuk V, Meunier FC, Ross JRH (2001) J Catal 202:340-353

[16] Liu IOY, Cant NW (2005) J Catal 230:123-132

[17] Bion N, Saussey J, Haneda M, Daturi M (2003) J Catal 217:47-58

[18] Yeom YH, Li M, Sachtler WMH, Weitz E (2007) J Catal 246:413-427

[19] He H, Yu Y (2005) Catal Today 100:37-47

[20] Chafik T, Kameoka S, Ukisu Y, Miyadera T (1998) J Mol Cat A 136:203-211

[21] Poignant F, Saussey J, Lavalley JC, Mabilon G (1995) J Chem Soc-Chem Comm 1:89-90

[22] Yeom YH, Li M, Sachtler WMH, Weitz E (2006) J Catal 238:100-110

[23] Can F, Flura A, Courtois X, Royer S, Blanchard G, Marécot P, Duprez D (2011) Catal. Today 164:474-479

[24] Sato T, Goto S, Tang Q, Yin S (2008) J Mater Sci 43:2247-2253

[25] Musi A, Massiani P, Brouri D, Trichard JM, Da Costa P (2009) Catal Letters 128:25-30

[26] Bethke KA, Kung HH (1997) J Catal 172:93-102

[27] Westerberg B, Fridell E (2001) J Mol Cat A 165:249-263

[28] Meunier FC, Breen JP, Zuzaniuk V, Olsson M, Ross JRH (1999) J Catal 187:493-505

[29] Kijlstra WS, Brands DS, Poels EK, Bliek A (1997) J Catal 171:208-218

[30] Parkyns ND, in: J.E. Hightower (Ed.), Elsevier, New york, (1993) 255

[31] Apostolescu N, Schröder T, Kureti S (2004) Appl Catal B 51:43-50

[32] Pozdnyakov DV, Filimonov VN (1973) Kinetic and Catalysis 14:665-669

[33] Ozensoy E, Herling D, Szanyi J (2008) Catal Today 136:46-54

[34] Bentrup U, Richter M, Fricke R (2005) Appl Catal B 55:213-220

[35] Shimizu K, Shibata J, Yoshida H, Satsuma A, Hattori T (2001) Appl. Catal. B 30: 151-162

[36] Yamaguchi M, Goto I, Wang ZM, Kumagai M (1999) Science and Technology in Catalysis 121: 371 374

[37] Burch R, Breen JP, Hill CJ, Krutzsch B, Konrad B, Jobson E, Cider L, Eranen K, Klingstedt F, Lindfors LE (2004) Topics in Catalysis 30: 19-25

[38D] Breen JP, Burch R (2006) Topics in Catalysis 39: 53-58

[39] Shimizu K, Shibata J, Satsuma A (2006) J. Catal 239: 402-409

[40] Yu Y, He H, Feng Q, Gao H, Yang X (2004) Appl Catal B 49:159-171

[41] Macleod N, Lambert RM (2003) Chem Commun 9:1300-1301

[42] Thibault-Starzyk F, Seguin E, Thomas S, Daturi M, Arnolds H, King DA (2009) Science 324:10481051 